Vol. 29 No. 1, 2017

DOI:https://doi.org/10.26725/JEE.2017.1.29.5823-5826

\title{
Constraints Faced by Farmers in Adoption of Organic Plant Protection Practices
}

\section{K.V. Aparna ${ }^{1}$ and Allan Thomas ${ }^{2}$}

\begin{abstract}
The study was conducted in Thiruvananthapuram district of Kerala with a view to identify the constraints faced by farmers during adoption of organic plant protection practices in vegetables. The three major constraints faced by farmers were crops being affected by drought, lack of proper and timely extension services for transfer of organic technologies and organic produce fetching non-remunerative price. The major suggestions for refinement were regular and frequent farm visits, diagnostic and consultancy by Krishi Bhavan officials and mechanisms to ensure premium price for products derived through organic practices.
\end{abstract}

Keywords : Organic plant protection practices; extent of adoption; constraints; suggestions

The side-effects of the modern agricultural chemicals and machines raise serious questions about the overall benefits of the new technology (Oelhaf, 1978). Chemical fertilisers and pesticides pollute our air and water. Agricultural chemicals, including hormones and antibiotics leave residue in food that may cause cancer or genetic damage. Soil and energy resources are being depleted. The un-sustainability of modern agricultural practices through its unscrupulous use have led farming communities world over to look for alternatives. The majority of these alternatives call for a back to nature policy, a return to traditional, eco-friendly practices. Organic farming is one among them. Organic farming over the last few decades has proved to be successful; but the differences in culture, ecology and geographical factors necessitate adoption of situationspecific principles and techniques. Many reports recommend popularisation of biofertilisers and green manures; to initiatea 'Green manure perennial planting Programme'; mechanical plants for manufacture of compost in Corporations and Municipalities, minimisation of use of insecticides; and to take up biological and mechanical control of rodents (Nair, 1981). The study by Balachandran (2004) reported the non-availability of organic plant protection formulations and

1. PG Scholar and 2. Assistant Professor, Department of Agricultural Extension, College of Agriculture, Kerala Agricultural University, Vellayani- 695522 
adequate quality organic manure which forced farmers to choose the chemical option, much to their dislike. Therefore constraints faced by the farmers using organic plant protection practices need to be identified and solutions to overcome the constraints as perceived by the farmers need to be probed. This paper is an attempt in that direction.

\section{METHODOLOGY}

The study was conducted in Thiruvananthapuram District of Kerala involving 90 small and marginal vegetable growers. From the eleven blocks of Thiruvananthapuram District, three blocks having maximum area under vegetable cultivation were selected. Perumkadavila, Nedumangad and Parasala were the three blocks selected for the study. From each block one panchayat having maximum area under vegetable cultivation was selected in consultation with agriculture department officials. Kunnathukal, Chenkal and Nedumangad were the three panchayats selected for the study. From each panchayat, 30 vegetable farmers were selected. Thus a total of 90 farmers formed the sample. A well structured open ended interview schedule was used for data collection from the farmer respondents. The results were analyzed with the help of different statistical tools such as frequency, percentage and rankings.

\section{FINDINGS AND DISCUSSION}

The constraints faced by the farmers using organic plant protection practices with more focus on vegetable cultivation were identified, documented and ranked. The results are presented in Table 1.

The primary constraint experienced by the farmers at the time of interview was that the crops were severely affected by drought. Lack of extension service to facilitate transfer of technology scientifically on organic plant protection was ranked second . Other major constraints that followed were, "produce fetching same price or even more than that of the produce obtained through inorganic practices; time consuming while resorting to organic plant protection input preparation, storage and its application; organic practices are labour intensive and non availability cum high cost of labour; krishi bhavan was not active in rendering support by way of helping farmers with quality inputs and services; lack of crop insurance schemes or facilities to help farmers mitigate the loss through price fall or crop loss as a result of practicing organic practices and lack of motivation resulting from low price for organic produce, in the decreasing order of importance as perceived by the farmers. 
Table 1.

Constraints faced by the Farmers in the Adoption of Organic Plant Protection Practices

$\mathrm{N}=90$

\begin{tabular}{|c|c|c|c|}
\hline S1.No. & Constraints & Score & Rank \\
\hline 1 & $\begin{array}{l}\text { Lack of extension service to facilitate transfer of } \\
\text { technology scientifically on organic plant protection }\end{array}$ & 299 & 2 \\
\hline 2 & $\begin{array}{l}\text { Lack of crop insurance schemes or facilities to help } \\
\text { farmers mitigate the loss through price fall or crop } \\
\text { loss as a result of practicing organic practices }\end{array}$ & 220 & 7 \\
\hline 3 & $\begin{array}{l}\text { Krishi Bhavan not active in rendering support by } \\
\text { way of helping farmers with quality inputs and } \\
\text { services }\end{array}$ & 234 & 6 \\
\hline 4 & $\begin{array}{l}\text { Time consuming while resorting to organic } \\
\text { plant protection input preparation, storage and } \\
\text { application. }\end{array}$ & 292 & 4 \\
\hline 5 & $\begin{array}{l}\text { Low effectiveness and slow action of organic plant } \\
\text { protection chemicals }\end{array}$ & 120 & 10 \\
\hline 6 & $\begin{array}{l}\text { Lack of knowledge and awareness about organic } \\
\text { plant protection practices }\end{array}$ & 114 & 11 \\
\hline 7 & $\begin{array}{l}\text { Non availability of subsidies and credit for organic } \\
\text { inputs }\end{array}$ & 174 & 9 \\
\hline 8 & Crops affected by drought (at the time of interview) & 303 & 1 \\
\hline 9 & $\begin{array}{l}\text { Organic produce fetched same price or even } \\
\text { more than that of the produce obtained through } \\
\text { inorganic practices }\end{array}$ & 297 & 3 \\
\hline 10 & $\begin{array}{l}\text { Lack of motivation resulting from low price for } \\
\text { organic agricultural produce }\end{array}$ & 181 & 8 \\
\hline 11 & $\begin{array}{l}\text { Organic practices are labour intensive/non } \\
\text { availability and exorbitant cost of labour }\end{array}$ & 240 & 5 \\
\hline
\end{tabular}


The top five suggestions to overcome the constraints as perceived by the farmers and subsequently finalized through focus group discussions are listed in Table 2.

Table 2.

Distribution of Respondents based on suggestions from Farmers.

\begin{tabular}{|c|l|c|}
\hline S1 No. & \multicolumn{1}{|c|}{ Suggestions } & Percentage \\
\hline 1 & $\begin{array}{l}\text { Regular and frequent farm visit, diagnostic and consultancy } \\
\text { by Krishi bhavan officials }\end{array}$ & 90.44 \\
\hline 2 & $\begin{array}{l}\text { Availability of low cost organic inputs and feasible } \\
\text { technologies }\end{array}$ & 88.33 \\
\hline 3 & $\begin{array}{l}\text { Inclusion of more no of classes, demonstrations and } \\
\text { seminars about organic plant protection practices }\end{array}$ & 75.22 \\
\hline 4 & \begin{tabular}{l} 
Timely access of organic plant protection inputs \\
\hline 5
\end{tabular} & \begin{tabular}{l} 
Construction of low cost mini dams or water storage facilities \\
\hline
\end{tabular} \\
\hline
\end{tabular}

Majority of the farmers (90.44\%) suggested that regular and frequent farm visits, diagnostic and consultancy by Krishi bhavan officials should be ensured at farm plots with standing crops. 'Availability of low cost organic inputs and feasible technologies should be provided at the right time in required quantity and quality' was the second popular suggestion as perceived by 88.33 per cent of the farmers. Inclusion of more number of classes, demonstrations and seminars about organic plant protection practices; followed by farmers right to have timely access to organic inputs and the construction of low cost mini dams or water storage facilities like technologies developed and popularised by Regional Agricultural Research station (RARS),
Ambalavayal were the other suggestions for refinement as perceived by the farmer respondents.

\section{REFERENCES}

Balachandran, V. (2004). Future in the Past: A study on the status of organic farming in Kerala. Discussion paper no. 82. Kerala research programme on local level development. Centre for development studies, Thiruvanthapuram, Kerala, 110p.

Nair, J. M. (1981). Report of the One Man Commission on the problems of Paddy cultivators in Kerala. Govt. of Kerala.

Oelhaf, R. C. (1978). Organic agriculture. Allanheld, Osmun \& Co. Publishers, Inc. USA. 